\title{
REOG AS MEANS OF STUDENTS' APPRECIATION AND CREATION IN ARTS AND CULTURE BASED ON THE LOCAL WISDOM
}

\author{
Sri Ambarwangi* \\ S. Suharto** \\ Teacher of Vocational School 1 Pringapus Semarang District, Indonesia \\ E-mail: sriambarwangi@gmail.com \\ Lecturer of Music Department, Semarang State University \\ E-mail: harto1965@gmail.com
}

Received: July 2013. Accepted: Februari 2014. Published: Maret 2014

\begin{abstract}
This paper is the result of the study and the implementation of learning in the field of the author, especially in the implementation of the study of Arts and Culture in the vocational schools. The purpose of this paper is to show that by learning local culture based on learning objectives the corresponding to the curriculum can be reached. In fact, the local culture also containing more local wisdom is felt directly by the students. The art of Reog, known around Pringapus Semarang Regency, can be used as means of learning arts for students, especially in the activities of appreciation and expressions. The existing values in the art of Reog can be conceptually presented in class, as well as directly through the students' activities of appreciation and expression in the form of performances in the school environment. Students can easily receive learning materials and can be more expressive while presenting the show. The values that are in the presentation of the art of Reog are social, religion, nationalism, and culture. Students can present Reog with enthusiasm and expressive as a show that has already exist since a long time in the environment of their own, and even many have become the performers of Reog in their neighborhood. Reog has already been part of his life that has the role of self-actualization, expression, social, and cultural. Most of those students feel proud to be a part in the show in his living quarters so that they do not feel ashamed of serving the art in school.
\end{abstract}

Keywords: Reog; Possessed; Based on Local Wisdom; Arts and Culture

\section{INTRODUCTION}

School-based Curriculum (KTSP Curriculum) of Arts and Culture for the non Vocational School of art in fact has already accommodated local arts grants to be awarded in the lesson. Its implementation has already given the freedom for education to develop units in accordance with the circumstances, the means, and the local environment. The standard of competence in art music and dance has already accommodated arts as a part of an aesthetic learning which includes artistic appreciations, creations, and expressions. There comes to a problem in learning that a large number of teachers have different interpretations. Even many just give Western art concepts due to their background of Western art without any opportunity for the students to understand the use of the concept and the expression. Thus, the learning objectives are not achieved.

Lack of understanding in application and different art background from the concept to be achieved in the curriculum lead to many different interpretations among teachers. It is understandable if teachers with educational background of Western music which has been ingrained in Wes- 
tern notation system should teach a different Javanese traditional music notation system. However, it does not mean that teachers should stop searching for new innovations to the implementation of learning the art of local traditions that indeed should be given will be stopped anyway since the learning objectives which are relevant to the competency standards in schools should include appreciations, expressions, and creations. And to achieve it, there are actually a lot of ways to be done by the teachers, both in class and outside of class.

It is wise to learn the art of tradition that comes from the local art. Learning resources in the form of abundant local art traditions around schools can be used in learning. This course will also enable teachers to provide the materials for the students that are accustomed to learn this tradition. This would be much better than giving Western music learning materials that are difficult for students to understand due to the infrastructure as well as the heterogenous background of students. Western music is really foreign to them.

SMK Pringapus is a state vocational school located in the village of Jatirunggo in sub-district Pringapus, whose territory borders on Boyolali Regency, Grobogan, and the town of Salatiga. For several years the author had difficulty in teaching arts to the students. Students still have not easily received the material of art music primarily in the concepts, such as notation of melodies, harmony, and so that West grammatical. Likewise in the management practices of learning music. This might be due to environmental background of the students who are still unfamiliar with the materials. Instead, they were pretty enthusiastic if invited to a discussion of the music traditions of the local area such as Reog.

Reog is a kind of art that has flourished since decades ago until now in Semarang district which borders on Boyolali Regency, Salatiga city, and Grobogan. It is like a kuda lumping, jaran kepang, and jathilan. Reog in Semarang district is not as grand as the show of Reog Ponorogo, but it has its own peculiarities customize existing local traditions in the area. Up to this point a show is always packed with hundreds of spectators, even thousands.

Reog could still exist and is favorable until now. The reason is in its functions as either an entertainment or other functions, such as the socio-cultural and ritual purposes. This is what inspires the author to investigate the arts in order to make it as a medium of appreciation and expression, including the creation of vocational students of Pringapus. During served in the school environment, it is always followed by enthusiastic students, both as a performer or a dancer as well as the audience. In fact, according to their testimony, they have become the performers of Reog since they were children. The author also explores their artistic endeavors in their living quarters, especially in the arts of Reog, so local values can be achieved when it is used as a medium of learning. The art of Reog has long grown and becomes a part of the life of the local community expression. It is believed to contain positive values that can be used in the world of education. Values that are believed to eventually become a part of the society, which are often called local wisdom, will facilitate this material as a medium of learning arts.

In accordance with its character, the lesson of Arts and Cultural has its own peculiarities and it has a specific purpose. The existence of Arts subject at schools is not to create artists, nor to brighten students with their math-logic. It is such a special purpose to soften the senses, intellectual, moral, and to strengthen the sense of nationalism. Besides psychologically, arts can help students develop their smooth and gentle nature and a sense of solidarity in accordance with the nature of art that it plays or invests (Dewantara, 1977; Adipal, 2010; Campbell, 2001) .

The values in the traditional arts are believed to be good for decades of life to be a right medium for students to express themselves and be creative if it can be managed well in the learning process. This could concern in the management of 
time or the exact subject matter, the determination of classes, and the performances of material parts accordingly. The parts that cannot be applied at schools can be selected without omitting the main substance in the Reog art. This is what authors continuously examine the implementation of learning the local tradition art especially Reog in SMK Negeri Pringapus.

\section{Role of Art Education in Schools}

Art music in school-based curriculum (SBC) of vocational schools is a piece of the Arts and Culture subjects, including other arts such as visual arts, dance and theater arts. In the background of the competency standards of this lesson serve an objectives amog other things: (1) to understand the concept and the importance of art and culture, (2) to show appreciation attitude towards art and culture, and (3) to express creativity through arts and culture (Depdiknas, 2006) .

Arts and Culture has its own distinctiveness or uniqueness that does not belong to other subjects, so learning this subject must be different from others any way. This is very beneficial to the development needs of students. In arts education, to achieve meaningfulness is known by the approach of "learning with arts", "learning through arts", and "learning about arts". The activity with this approach is to provide an aesthetic experience in the form of creative activity or expression, and appreciation. "Learning with arts" implies that in any learning activities we can engage the art in it. For example, studying while listening music. "Learning through arts" implies that the art can be used as a means to learn things or other fields. For example, in learning songs, while learning music we could also learn literature, history, nationalism, social, religion, and others. This concept is embraced the notion popularized by Read (1970), known by the approach to education through art. "Learning about arts" means that to achieve the aesthetic goals students can directly learn arts covering all aspects of the art. For example, when learning music students are expected to master it or the learning objectives in order to be able to sing or play music that is suitable for the purpose of the lesson.

An arts education with its own characteristics makes it have a special purpose in achieving the goals of general education. There are three properties owned by the education of Arts and Culture; they are the nature of multilingual, multidimensional, and multicultural. Multilingual means the development can be done in various ways and media, such as visual arts, sound, motion, roles, and the mix of those media. Multi-dimensional means the development of competencies that includes conception, appreciation, and creation by blending harmoniously with the elements of aesthetics, logic, kinestetics, and ethics. And, multicultural competency means the development of competencies through meaningful activities that lead to an appreciation of the cultural diversity of Indonesia and foreign countries.

Music education has its own domain which is different from other fields, such as mathematics which is farming out the domain of logics. The field of art is a sense and appreciative attitude that can be achieved through the activities of appreciation and creation to meet the individual needs of harmony. Arts and Culture is a group of subjects which has the aesthetic characteristics of learning distinctive competence and standard in the achievement of basic competencies (Ambarwangi, 2013, p. 78).

Human beings essentially have multiple intelligence which is not based solely on intelligence and logical, but other intelligence. According to Gardner (1993), human beings have multiple intelligences among others (1) linguistics (functional language proficiency), (2) logical-mathematical intelligence (the ability to think coherently), (3) musical intelligence (the ability to capture and create a pattern of tones and rhythm), (4) spatial intelligence (the ability to form mentally images about reality), (5) physical-kinesthetic intelligence (the ability to produce fine motor movements), (6) intra-personal intelligence (the 
ability to know yourself and develop a sense of identity), and (7) interpersonal (social) - the ability to work effectively with others, connect with others, and to show empathy and understanding, to observe their motivations and goals. Interpersonal intelligence (the ability to understand other people). Music teachers can take advantage of the nature of human intelligence to get the whole musical concepts by exploring all the existing potential. Any effects resulting in the art education in schools will lead to general education purposes. Students who have achieved the standard of high appreciation and creation could be the ones who like to respect others, creative, gentle, tolerant, able to come up in public, self-confident, even intelligent. Human traits with these properties are not parts of the general education objectives of various types of education. It is not possible to achieve the objectives of education only through the kind of education that involves the left hemisphere of logical, analytical, systematics, and so on, but also involves the right hemisphere of intuition, imagination, innovation, synthesis (holistic), creations and so on which are obtained through arts activities, such as rhythm, tone, color (DePorter and Mike Hernacki, 2000, p. 27). Students who are active in the choir, for example, will be familiar with the nature of the work, like helpful, tolerant and respect other people's love, harmonious, have a high musical taste, gentle, confident and disciplined. It is all a direct result caused in the process of training up to her appearance. That is to be expected in the general education goals.

One important thing to enhance the creativity and intelligence of the students is a tribute to local culture itself. Because the local culture is the basis for the character of a society as well as the success of an educational attitude parameters.

Local wisdom often called a local genious can be understood as a human effort using his intelligence (cognition) to act and to behave towards things, objects, or events that occur in a given space. This definition is arranged in etymology, in which wisdom is understood as the ability of a person in using reasonable mind to act or to behave as a result of an assessment of things, objects, or events that occur (Ridwan, 2007, p. 27).

Local specifically refers to a limited interaction space with a finite system of value. As an interaction space that has been designed in such a way that it involves a relationship pattern of man with man, or man with his physical environment. These patterns of interaction that have been designed are called settings. It is an interaction space in which one can sort the face-to-face relationships among their environment. A life setting that is directly formed will produce values. These values will be the cornerstone of their relationship, or as a reference for their behavior.

For example, local genius that still persist in the life of Javanese is a Javenese psychological notion. This psychology is a kawruh Javenese psychiatric. This includes the volatility of reason, sense, and desire of Javenese people to hold their lives. A Javanese generally lives in psychiatric world (Endraswara, 2003, p. 211). Values of begja, watak nrima and rasa rumangsa are examples of local knowledge which generally embrace Javanese people.

The tradition art is a living art tradition in the area with a tradition and local wisdom enclosing. Values that exist in both the background of the creation as well as existing symbols in the tradition art are local tradition alive hereditary for generations.

The cultural values in a particular society are supposed to only be quatified with the local culture rather than other cultures. This is due to the reason that something that is considered to be good in certain communities may not be good in others. Because these values are only produced by a system that is local to a specific cultural value thus cannot be measured with the system originating from other cultural systems, though it is considered universal. For this case then comes the indigenous psychology that first appeared in the 1970s in Asian region. The core of this study is 
that psychological theories from the West into six sections, namely a private functicould not be used as a basis for the study on, social, physical, religious, educational, of people from Eastern societies that were and economical functions.

local and came from different cultural sys- As one of the cultural elements, art tems. Kim and Berry (1993) define an indi- has a function as a reference of action to its genous psychology as the scientific study supporters. As a cultural system, to meet of human behavior or mind that is native, the needs of aesthetic, art can serve as a rethat is not transported from other regions, gulator, manager, or controller in arts acand that is designed for its people. Today tivities. This exists in the traditional arts. many scientists both anthropologists as As a system, therefore, the function of art well as psychology experts use this as an is not just usability, but it is meant to funapproach to his research.

\section{METHOD}

This type of research is classified into qualitative research using analytical and descriptive writing and ethnomusicology approach. Ethnomusicology is a research approach to understanding the music concept of community maker. Researchers can learn to feel, plays, expressed in accordance with those of society. The study of music in the context of culture according to Merriam (1964), known as a model for the study tripated Ethnomusicology can be studied from three levels, namely (1) the concepts of music, (2) the behavior of both players and music lovers, and (3) the sound of the music itself. Thus the study of ethnomusicology should also not far from the three aspects in analyzing the data. Techniques of data collection by interview, observation, and documents. Data were analyzed with the interactive analysis technique of Miles and Huberman with the ethnomusicology research approach.

\section{RESULT AND DISCUSSION}

\section{Functions of Traditional Arts in Human Life}

The emergence of art, whether nonphysical or physical arts has functions for human beings or their lives. Art has taken a role in the progression of human civilization in the world since prehistoric times until the contemporary. Thus the function of art can vary in line with the human civilization. According to Chapman (in Setiawan, 2012) the function of art is divided ction as something that can be donated on a particular party in a system. The art develops and standardizes through the arts of social traditions of a society (Parsons, 1951, Rondhi, 2002, Triyanto, 1994, Rohidi, 1993).

Thus, it is clear that an art would disappear when it is no longer a part of the particular cultural system of society. A particular art tradition will be lost if no longer used for ritual, social events, as well as entertainment. Its current status is not a cause of art to be manifold, one of which is a shift in culture that exists in society such as the globalization era, an era in which the influence of technology is so powerful to change society.

\section{Traditional Arts Reog}

Reog, or something like kuda lumping, ebeg, jatilan, and kuda kepang are already known in the Javanese community. These arts have become a national art which was in the past concentrated to mystical ( $n d a-$ $d i$, or possessed) as one of its appeals. In fact, groups of Javanese, wherever they are in the world, almost have a group of $k u d a$ lumping (Suara Merdeka, 15 September 2012).

If it is seen from the property used, the form of performances, as well as the background of the meaning behind the art, Reog has similarities with other arts. Reog and similar types of art, have players/dancers using artificial horse made of woven braided bamboo, or animal skin/lumping, then they dance to form such as cavalry formations, by providing elements of magic as one of its appeals. Sometimes in some areas such as Kebumen, Brebes, and 
elsewhere add barongan and penthul as an integral part. In Ponorogo, this kind of art has become a magnificent show with a fully equipped property with the name Reog Ponorogo .

This art has exist and continue to be preserved for generations without being known who and when first played. Nevertheless, the community support this kind of art and consider that it is part of their life as an aesthetic expression, the expression of joy, anger, a sense of mutual, even a sense of nationalism or heroism.

Of the form of the show, this art reflects the expression of an egalitarian society, but also patriotic. As well as other folk art, this is not art since the feudal appears as reverence and devotion the people on him (The King). This art appears as if the supporters are already aware of their positions just as the commoners. It can be seen from the meanings in any parts of the show that are filled with symbols. The role of Barongan (or Barong in Brebes) symbolizes a King or a leader who has the right to receive money (tribute) from the audience, and the role of penthul as a symbol of the king's advisers, who despite his small but highly appreciated by the king, or other players.

The interesting part of this art performance events is ndandi after the ritual of burning incense. People who perform this ritual should be considered a qualified person as it is considered for the supporters as an important part that do not mess around. The ritual of burning incense symbolizes the beliefs of the ancient Javanese that still believed in animism and dynamism as well as the influence of Hinduism. In some particular areas, it is a symbol of devotion to God that shall pray for salvation. In fact, kuda lumping in Brebes is to summon spirits. It could be either the ghosts of deceased ancestors or deceased animals. While in the areas that are still close to the palace of Surakarta and Yogyakarta, the ritual of burning incense is a symbol of prayer or asking for help on satyrs or ethereal (especially those considered to be good) to help the fight like in the story of the show. The cavalry troops depicting brave Mataram troops still have to get reinforcements from the invisible army of Nyi Rara Kidul in each battle. At least, that is the myth that Javanese community believed that this kind of art was expressed in a scene of burning incense in the show (Ananda, 2011).

\section{Reog Art as Expression and Art Apprecia- tion of SMK Pringapus Students}

The state vocational school of Pringapus is located less than $15 \mathrm{~km}$ from the downtown of Semarang Regency to the east. This school is built on hilly ground which is not much different from the hilly environment surrounding area. Most of the students come from the surrounding areas close to the borders of Boyolali Regency, Grobogan, and Salatiga. The school is located on the outskirts of the city that was originally set up to accommodate people from the outskirts of the city to meet the needs of the garment industry that happens to set up around the area garment industry. One of the departments in this school is fashion, and the others are the engineering automotive to motorcycle and multimedia.

The subject of Arts and Culture is one given in each class which include music, dance, and visual arts. However, since there is only one teacher whose educational background is music, then the music class is more dominant, although it only lasted a few years. Next, the teacher is doing innovation as the response to students that the music lesson is less encouraging. The lack of a good response from these students is more because most materials are presented a lot of Western music notation and other types of diatonic music. Whereas a lot of students are from the communities that cultivate the traditions of art like Reog. Finally, the author, as one of the teachers of the Art and Culture utilize Reog as a medium to convey the material of culture and arts, ranging from theoretical studies to showing Reog presentation at the school by students.

Reog is a traditional art that has 
existed for decades in the region. Many Reog groups are establieshed in this region and frequently perform for both institutions and individuals. Reog similar art with jaran kepang, jathilan, ebeg, and reog Ponorogo remains a kind of art that is in great demand by the local community. Every show is always attended by hundreds of people around.

Reog performances in school is one of the programs that is always done in state vocational school of Pringapus. In addition to channel students' interests and means of expression at the arts, it is an effective medium in learning culture as well as growing sense of social solidarity and national unity. Reog performances in the school are expected to be used as a means of instilling a sense of solidarity, mutual aid, in addition to the symbolic values of heroism that exist in Reog. Because it is a symbol of heroism which describe the gallant troops who drive horse (Interview with Sunoto, the leader of Reog Turonggo Jati, dated May 25, 2013).

The performance of tradition arts in school can also instill values directly to students through the expression and appreciation activities like Reog. Cultivating of mutual respect over the tradition arts by the students is also a concrete manifestation forms of multicultural lessons for students. The cultivating of multicultural education is suitable provided through arts can be very effective if properly managed (Ambarwangi, 2013, p. 78-85). Students who play and watch alike learn through the performing tradition arts like Reog. When playing Reog they can directly express the arts and feel a sense of solidarity and togetherness, mutual trust, mutual respect while coordinating these performances. Likewise, students who watch. They can appreciate it, and can appreciate friends who enthusiastically express the tradition arts.

Being Reog player in the community in which they live is a pride, they do it with no shame to show that expression in the school environment. With these values are believed to be good and proven over deca- des this art still exist. They enjoy the show including the performance of possessed or ndadi. Nevertheless the ndadi is less vulgar when performed at schools.

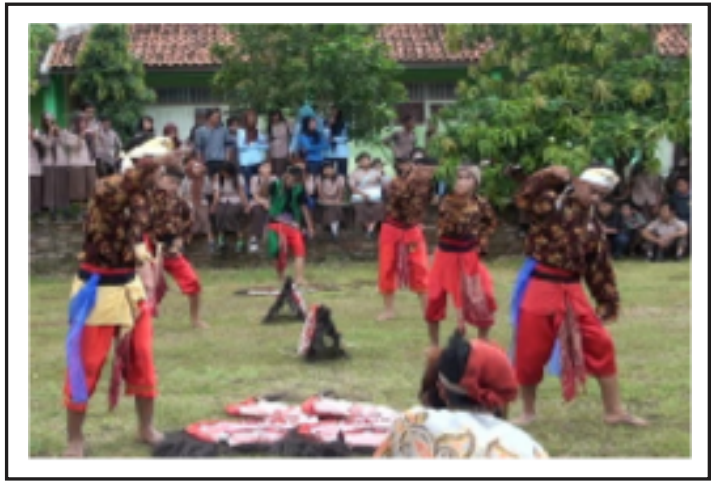

Figure 1. Vocational High School students Playing at School

Ndadi or possessed is a highly anticipated attraction by audiences in each performance of Reog, jaran kepang, and many others. According to Sunoto Parmin, a handler of Reog Turonggo Jati Pringapus, the type of ndandi can vary depending on the spirits called. The ghosts could be the deceased animal spirits, genies/demons, and ancestral spirits. If the spirits are summoned by the handler the spirits of the animal, then the dancer will behave like animals so they can eat the leaves or climb trees very quickly like a monkey. The author can see when viewing the show of Reog Turonggo Jati group. A dancer suddenly climb the coconut trees around the area of show very quickly as a monkey.

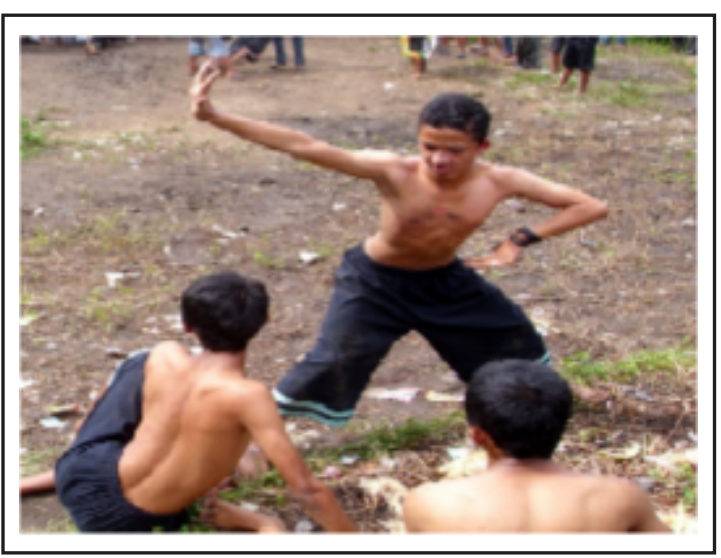

Figure 2. Players who take her clothes off and dance for ndadi 
The performance of ndadi at schools can be packed solely for entertainment and a means of artistic expression for the students. The deceased animal spirit can be summoned so the performer only eats the leaves. However, according to one of the dancers, Faisal, this ndadi can pretend if his intention is simply to entertain. If you do not believe the incident, ndadi will not happen; all happened is pretense. However, if the offender believe it, then he will actually be possessed. And have a professional handler who can do that, either when making ndadi to healing or reviving.

\section{Value of Local Wisdom in Reog and its Functions in Pringapus}

Ndadi can possibly happen as the spirits are called and enter the soul of the player when the handler prays to call. Praying to summon spirits and burning incense is a symbol of faith to always pray to God. According to one of the religious leaders, Qozin (35) most of the communities around the Pringapus sub district is not real Islam (Islam Abangan). Animism and dynamism as well as very strong Hindu influence are in their spiritual lives.

There are distinct positive values in the show either it is done at school or in the community where this art came from. Positive values in the school have been discussed in item 3.1 above. The existing values in the community can be felt when the author made observations and interviews with the leaders and performers on the field. The reception was very friendly and enthusiastic as one evidence that appreciate the guests is one that should be done by every citizen. Even the author was given the freedom to cover every show without any interference from the dancers on the stage. Another positive value is that the players supporting a group totaling 40 personnels very easily coordinated by the group leader. Their solidarity is very high. They never compete in the income problem. Often the money the group received ranges from 3 to 4 million per show to be saved for the group once. That money could be used for social activities of the community. Even the way the money can be obtained dues to every citizen, especially if the response is in order along with ritual and celebration events like merti desa.

From the explanation above it is clear that the art community for the Reog Pringapus supporters has social functions. Collecting societies in which they mutually interact in a single art activity they like and most of them simply do not get any rewards are strong evidences of the local community to commit to building a society and its culture. And, this will make the traditional art Reog will continue to exist in this area.

The care of the society has been proven when recruiting many teenagers involving to be dancers. It proves a great support from the community towards art to remain sustainable. Moreover, the music players and the dancers are mostly from students of the state vocational school and the ones graduated from the school in which the author serves. It will be a very natural model of inheritance, in addition to the continued support of education in holding Reog performances in the school environment with special packaging for the world of education.

\section{CONCLUSION}

Reog in the region of Semarang District still exist since there is good support from all elements of the community supporters, local governments, as well as the education world. However, another element that stands out is because of the functions of art to the community. Those functions such as for personal aesthetic needs, the social needs as a means of interacting with others in order to meet the social needs of collectivity, as well as spiritual needs, and cultural functions. These functions work systematically to establish a separate system to create harmony in the society in the Pringapus district. If the value of harmony is drawn into the world of education, it will give a positive effect. The show runs well since it is maintained by the community, can be the lesson and lear- 
ning in schools. These values, in addition to other positive values, can be packed into one of the cultural arts media, in which the role of the Cultural Arts lessons can be very strategic to build the characters of students.

The implementation of Arts and Culture subject by bringing local art that is believed to contain local wisdom in Pringapus vocational schools is a synergistic effort due to the fact that most of the learners are also the actors of these arts in their areas. The duty of teachers and education units is to relate it in the management and selection of material, so it is completely consistent with the objectives of art education in the public schools as a means of appreciation, creation, and expression for students. Thus, an art education has a special purpose to be really useful in the framework of achieving the objectives of education in general.

The results of this study can be used as an input in order to find a learning model of the Arts and Culture on the basis of local wisdom of the area where the school is located. Therefore, it is necessary to hold a comprehensive study covering all aspects. Those studies could be Classrom Action Research (CAR), School Action Research for the supervisors and principals, as well as a cultural research. This is so for the results of this comprehensive study in finding the results of a learning model that is suitable for learning Art and Culture subject in schools.

\section{REFERENCES}

Alik, S. (2013). Fungsi Seni dalam Kehidupan Manusia. Retrieved http://alixbu miartyou.blogspot.com/p/biografi. html. May 15, 2013.
Ardipal. (2010). Kurikulum Pendidikan Seni Budaya yang Ideal bagi Peserta Didik di Masa Depan. Jurnal Bahasa dan Seni. 11(1).

Ananda. (2011). Ebleg Akar Kesenian Kuda Lumping. Retrieved http://adisulistyo.wordpress. com/2011/05/06/ ebleg-akar-kesenian-kuda-lumpingebleg-the-root-of-traditional-kudalumping-dancing. May 16, 2013.

Campbell, D. (2001). Efek Mozart bagi Anakanak. Jakarta: Gramedia Pustaka Utama.

DePorter, B. \& Mike Hernacki. (2000). Quantum Learning. Transalated by Alwiyah Abdurrahman. Jakarta: KAFIFA

Dewantara, K.H. (1977). Pendidikan Bagian Pertama. Yogyakarta: Majelis Luhur Persatuan Taman Siswa.

Endraswara, S. (2003). Mistik Kejawen: Sinkretisme, Simbolisme, dan Sufisme dalam Budaya Spiritual Jawa. Yogyakarta: Narasi.

Gardner, H. (1993). Multiple Intelligences: From Theory to Practice. New York: Basic Books

Kim \& Berry. (2006). Indigenous and Cultural Psychology: Understanding People in Context. New York: Springer.

Mack, D. (2005). Musik di antara Seni dan Politik: sebuah Dilema Abadi. Pengantar dalam buku Ismail Marzuki Musik, Tanah Air dan Cinta. Jakarta: LP3ES

Merriam, A.P. (1964). The Antropology of Music. Bloomington: Northwestern University Press.

Permendiknas, RI No 22 Tahun 2006. "Tentang Standar Isi untuk Satiuan Pendidikan Dasar dan Menengah". Jakarta: Depdiknas. 